\title{
PENGARUH TINGKAT PENGETAHUAN HUBUNGAN SEKSUAL BERISIKO TINGGI TERHADAP KEJADIAN INFEKSI GONORE DI RSUD Dr. SAIFUL ANWAR MALANG
}

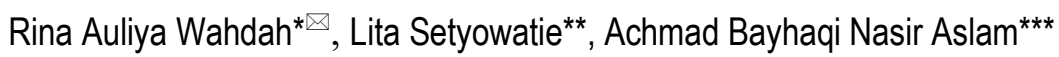

Abstrak

\begin{abstract}
Gonore adalah infeksi menular seksual (IMS) yang dapat terjadi pada laki-laki dan perempuan yang disebabkan oleh bakteri diplokokus Gram negatif, Neisseria gonorrhoeae. Insiden infeksi gonore tahun 2014 di RSUD. Dr. Saiful Anwar Malang (RSSA) diketahui sebanyak 60 orang dari total 399 pasien IMS. Tahun 2015 , tercatat 34 orang pasien infeksi baru gonore. Kejadian ini meningkat karena beberapa faktor di antaranya adalah pengetahuan dan hubungan seksual berisiko tinggi, yang tampak saat ini merupakan sebagian kecil dari keseluruhan pasien IMS. Tujuan penelitian adalah untuk mengetahui pengaruh tingkat pengetahuan terhadap hubungan seksual berisiko tinggi serta terhadap kejadian infeksi gonore di RSUD Dr. Saiful Anwar Malang. Populasi adalah pasien laki-laki terinfeksi gonore yang datang ke RSSA berjumlah 93 orang dan berdasarkan formula Lemeshow didapatkan. sampel sebanyak 36 responden. Pengambilan sampel dengan metode consecutive sampling. Path analysis (analisis jalur) dilakukan untuk menemukan penjelasan mengenai pengaruh langsung dan tidak langsung dari variabel tingkat pengetahuan, hubungan seksual berisiko tinggi, dan infeksi gonore berdasarkan beberapa pertimbangan teoritis serta pengetahuan peneliti yang ditampilkan dalam bentuk diagram jalur yang berfungsi untuk membantu dalam melakukan konseptualisasi masalah yang kompleks dan mengenai implikasi empirik dari teori yang sedang diuji. Hasil menunjukkan bahwa tingkat pengetahuan memiliki pengaruh yang signifikan dan berpengaruh positif terhadap hubungan seksual berisiko tinggi. Dapat disimpulkan bahwa tingkat pengetahuan terhadap hubungan seksual berisiko tinggi memiliki pengaruh yang signifikan terhadap infeksi gonore, namun tidak berpengaruh signifikan terhadap kejadian infeksi gonore. Serta, tingkat pengetahuan tidak berpengaruh signifikan terhadap infeksi gonore melalui hubungan seksual berisiko tinggi, dan hubungan seksual berisiko tinggi tidak berpengaruh signifikan terhadap kejadian infeksi gonore.
\end{abstract}

Kata kunci: hubungan seksual berisiko tinggi, infeksi gonore, tingkat pengetahuan.

THE INFLUENCE OF KNOWLEDGE LEVEL OF HIGH-RISK SEXUAL BEHAVIOUR AGAINST
GONORRHEA INFECTION INCIDENCE AT Dr. SAIFUL ANWAR PUBLIC HOSPITAL MALANG Abstract

Gonorrhea is a sexually transmitted infection (STI) that can occur in both men and women caused by the Gram-negative diplococcal bacteria Neisseria gonorrhoeae. In 2014 at Dr. Saiful Anwar Public Hospital Malang, it was found 60 people with gonorrhea infection from a total of 399 STI patients. Meanwhile, in 2015 there were 34 patients with new gonorrhea infections. This incidence increases due to several factors including knowledge and high-risk sexual behaviour, and what appear now are a small proportion of all STI patients. The purpose of this study was to know the influence of knowledge level on high-risk sexual behaviour as well as on gonorrhea infection, and to know gonorrhea infection incidence at Dr. Saiful Anwar Public Hospital Malang. The population was all male patients infected with gonorrhea which numbered 93 people and by using the Lemeshow formula, it was obtained as many as 36 respondents. Technique of sampling with consecutive sampling method and path analysis is conducted to find an explanation of the direct and indirect effects of knowledge of level, high-risk sexual behaviour, and gonorrhea infection variables based on theoretical considerations and the knowledge of researchers displayed in the form of a path diagram that serves to assist in conceptualizing complex problems and on the empirical implications of the theory being tested. The results showed that the knowledge level had a positive effect and significant on high-risk sexual behaviour. The conclusion is that the on high-risk sexual behaviour significantly affect the gonorrhea infection, but not in the incidence gonorrhea infection. Moreover. The knowledge level not significantly affect the gonorrhea infection trough high-risk sexual behaviour, and high-risk sexual behaviour do not affect the incidence gonorrhea infection.

Keywords: gonorrhea infection, high-risk sexual behaviour, knowledge level.

* Program Studi Pendidikan Dokter (S1), Fakultas Kedokteran, Universitas Brawijaya

${ }^{* *}$ Departemen IImu Kesehatan Kulit dan Kelamin, Fakultas Kedokteran, Universitas Brawijaya-RSUD. Dr. Saiful Anwar, Malang

*** Departemen Radiologi,,Fakultas Kedokteran, Universitas Brawijaya-RSUD. Dr. Saiful Anwar, Malang

$凶$ E-mail: rinaauliya4292@student.ub.ac.id 


\section{Pendahuluan}

Gonore adalah infeksi menular seksual yang dapat terjadi pada laki-laki dan perempuan yang disebabkan oleh bakteri diplokokus Gram negatif, Neisseria gonorrhoeae. ${ }^{1}$ Di Indonesia, prevalensi infeksi gonore yang dilaporkan oleh Survei Terpadu Biologis dan Perilaku mengalami kenaikan di Yogyakarta dan Tangerang pada tahun 2013 jika dibandingkan dengan prevalensi pada tahun 2009. Prevalensi gonore di Yogyakarta sebesar $25 \%$ dan di Tangerang juga tinggi, yaitu sebesar $32,8 \%$. Di Makassar pada tahun 2009, prevalensi gonore mengalami penurunan dari yang sebelumnya sebesar $12,5 \%$ menjadi $6,8 \% .^{2}$

Pada tahun 2014 di RSUD. Dr. Saiful Anwar Malang diketahui angka insiden infeksi gonore sebanyak 60 orang dari total 399 pasien IMS. Sementara pada tahun 2015, tercatat 34 orang pasien infeksi baru gonore. Sekilas dalam kurun waktu 2 tahun tersebut terjadi penurunan, namun perlu diketahui bahwa jika kejadian IMS ini dapat meningkat karena beberapa faktor yang mempengaruhinya dan yang tampak saat ini merupakan sebagian kecil dari keseluruhan pasien IMS. ${ }^{3}$

Peningkatan infeksi gonore dapat dipengaruhi oleh beberapa faktor di antaranya adalah pengetahuan dan hubungan seksual berisiko tinggi. Ada beberapa faktor internal dan eksternal yang mempengaruhi pengetahuan di antaranya pendidikan, pekerjaan, dan umur, sedangkan untuk faktor eksternal yang mempengaruhi adalah faktor lingkungan dan sosial budaya. ${ }^{4}$

Faktor yang mempengaruhi hubungan seksual (sexual intercourse) berisiko tinggi apabila memiliki pasangan seksual lebih dari satu, pernah mengalami infeksi menular seksual, dan perilaku seksual berisiko tinggi. ${ }^{5}$

Berdasarkan fenomena di atas perlu dilakukan penelitian tentang pengaruh tingkat pengetahuan terhadap hubungan seksual berisiko tinggi serta implikasinya pada kejadian infeksi gonore pada pasien gonore di RSUD. Dr. Saiful Anwar Malang. Selain itu, ingin diketahui korelasi antara tingkat pengetahuan dan hubungan seksual berisiko tinggi terhadap infeksi gonore agar didapatkan pengetahuan tentang fenomena yang terjadi sehingga masyarakat dapat mewaspadai penularan gonore.

\section{Bahan dan Metode}

\section{Desain Penelitian}

Desain penelitian adalah observational analytic dengan pendekatan cross sectional. Selanjutnya data yang telah diperoleh dianalisis menggunakan analisis jalur (path analysis). Penelitian ini telah mendapatkan persetujuan laik etik dari Komisi Penelitian Etik Kesehatan, Fakultas Kedokteran, Universitas Brawijaya dengan nomor: 185/EC/ KEPK-S1-PD/06/2019.

\section{Metode Penelitian}

Metode yang dilakukan secara consecutive sampling yaitu pemilihan subjek penelitian sebagai sampel secara berurutan. Semua pasien yang telah memenuhi kriteria baik inklusi maupun eksklusi dipilih sebagai sampel sampai besar sampel yang diinginkan terpenuhi. Kriteria inklusi yaitu: subjek penelitian adalah pasien berjenis kelamin laki-laki yang bersedia mengikuti penelitian dan telah menandatangani informed consent, bersedia mengisi kuisioner, dan pernah gonore. Kriteria eksklusi yaitu: subjek penelitian yang tidak bisa berkomunikasi secara verbal (tidak komunikatif dengan peneliti), berjenis kelamin perempuan yang pernah terinfeksi gonore, penyakit infeksi menulat seksual yang memiliki gejala yang sama seperti gonore.

\section{Populasi dan Sampel Penelitian}

Populasi yang digunakan merupakan kumulatif subjek penelitian pada tahun 2017 yaitu sebanyak 31 orang dan pada tahun 2018 sebanyak 62 orang, 
sehingga total populasi dalam penelitian ini sebesar 93 orang yang datang ke RSUD Dr. Saiful Anwar Malang. Besar sampel minimal yang digunakan dalam penelitian ini menggunakan rumus Lemeshow dan didapatkan sampel minimal sebesar 36 .

$$
\begin{aligned}
\mathrm{n} & =\frac{\left(\mathrm{Z}_{1-\frac{a}{2}}\right)^{2} \mathrm{PqN}}{\mathrm{d}^{2}(\mathrm{~N}-1)+\left(\mathrm{Z}_{1-\frac{a}{2}}\right)^{2} \mathrm{Pq}} \\
& =\frac{(1,96)^{2} \times 0,50 \times 0,56 \times 93}{(0,05)^{2}(93-1)+(1,96)^{2} \times 0,50 \times 0,50} \\
& =35,726.88 \approx 36
\end{aligned}
$$

\section{Prosedur Pengambilan Data}

Data subjek diambil dari rekam medis pasien dengan cara memilihnya berdasarkan kriteria inklusi yaitu subjek penelitian adalah pasien berjenis kelamin laki-laki yang bersedia mengikuti penelitian dan telah menandatangani informed consent, subjek penelitian adalah pasien berjenis kelamin laki-laki yang bersedia mengisi kuisioner, dan subjek penelitian adalah pasien berjenis kelamin lakilaki yang pernah gonore.

\section{Analisis Data}

Data yang diperoleh berupa jawaban responden atas kuesioner yang telah disebarkan. Analisis data pada penelitian ini menggunakan program SPSS versi 24.0 for Windows. Data yang diperoleh dianalisis dengan teknik analisis deskripif dan analisis inferensial. Statistik deskriptif menunjukkan data dari poin-poin pada kuesioner penelitian. Statistik inferensial digunakan untuk menguji hipotesis yang diajukan dan generalisasi data sampel terhadap populasinya.

Skoring untuk tingkat pengetahuan menggunakan skala Guttman dengan jawaban benar (B), salah (S), dan ya atau tidak. Skoring untuk hubungan seksual berisiko tinggi menggunakan skala Likert dimana jawaban sangat sering (SS) diberi skor 5 , sering (S) diberi skor 4, cukup sering (CS) diberi skor 3, tidak pernah (TP) diberi skor 2, dan pernah $(\mathrm{P})$ diberikan skor 1.

\section{Hasil}

Pada penelitian ini dari 40 pasien yang pernah menderita gonore di RSUD Dr. Saiful Anwar Malang sebanyak 100\% responden adalah berjenis kelamin laki-laki dikarenakan peneliti hanya mengambil sampel dari pasien gonore yang berjenis kelamin laki-laki saja, dan sebanyak $67,5 \%$ yang pernah menderita gonore adalah pasien dengan usia di atas 25 tahun. Sebagian besar pendidikan terakhir pasien yang menderita gonore di RSUD Dr. Saiful Anwar Malang adalah SMA dengan persentase sebanyak $75 \%$ dan persentase pekerjaan paling banyak adalah sebagai mahasiswa dengan persentase sebanyak $55 \%$ (Tabel 1).

Pada kelompok risiko tinggi yang diteliti didapatkan sebanyak $52,5 \%$ responden adalah kelompok risiko tinggi (RISTI) LSL dan diikuti dengan kelompok risti biseksual dengan persentase sebesar 45\% (Tabel 2).

Seberapa besar tingkat pengetahuan yang dimiliki responden, dapat diketahui dengan mengajukan beberapa pertanyaan yang perlu dijawab terkait dengan informasi yang didapatkan mengenai infeksi gonore, transmisi saat berhubungan seksual dan pencegahan infeksi gonore, serta jumlah pasangan. Secara terperinci dapat dilihat pada Tabel 3 dan 4.

Berdasarkan Tabel 3, sebanyak $85 \%$ responden menyatakan pernah mendengar tentang infeksi gonore melalui media, 40\% responden menyatakan pernah mendengar tentang infeksi gonore saat ada penyuluhan, dan sebanyak $20 \%$ responden menyatakan pernah mendengar tentang infeksi gonore melalui brosur/leaflet, serta responden menyatakan pernah mendengar tentang infeksi gonore melalui teman sebanyak $73 \%$. 
Hal ini menunjukkan bahwa sebagian besar pasien yang pernah menderita infeksi gonore di RSUD Dr. Saiful Anwar Malang yang terlibat dalam penelitian ini menyatakan pernah mendengar tentang infeksi gonore melalui media sosial lebih dominan dibanding- kan media yang lain. Analisis deskriptif pada variabel tingkat pengetahuan tentang infeksi gonore melalui hubungan seksual berisiko tinggi diinformasikan melalui distribusi frekuensi pada Tabel 4.

Tabel 1. Karakteristik subjek

\begin{tabular}{lcc}
\hline Karakteristik Dasar & Frekuensi & Persentase (\%) \\
\hline Jenis Kelamin & 40 & 100,0 \\
Laki - laki & - & 0,0 \\
Perempuan & & \\
Usia (tahun) & 2 & 5,0 \\
15 - 19 & 11 & 27,5 \\
20 - 24 & 27 & 67,5 \\
$\geq 25$ & & \\
Pendidikan terakhir & - & 0,0 \\
SD & 5 & 12,5 \\
SMP/Sederajat & 30 & 75,0 \\
SMA/Sederajat & 5 & 12,5 \\
Akademi/Perguruan & & \\
Tinggi & & \\
Pekerjaan & 1 & 2,5 \\
Pegawai Negeri & 12 & 3,0 \\
Pegawai Swasta & - & 0,0 \\
TNI/POLRI & 22 & 55,0 \\
Mahasiswa/pelajar & 5 & 12,5 \\
Lainnya & & \\
\hline
\end{tabular}

Tabel 2. Kelompok risiko tinggi

\begin{tabular}{lcc}
\hline \multicolumn{1}{c}{ Kelompok Risiko Tinggi } & Frekuensi & Persentase (\%) \\
\hline Pelanggan Pekerja Seks (PPS) & 1 & 12,5 \\
Laki-laki berhubungan Seksual & 21 & 52,5 \\
dengan Laki-laki (LSL) & 18 & 45,0 \\
Biseksual & 18 \\
\hline
\end{tabular}


Tabel 3. Tingkat pengetahuan mendengar tentang infeksi gonore

\begin{tabular}{lcc}
\hline \multicolumn{1}{c}{ Media } & Frekuensi & Persentase (\%) \\
\hline $\begin{array}{l}\text { Media sosial } \\
\text { Ya }\end{array}$ & 34 & 85,0 \\
$\quad$ Tidak & 6 & 15,0 \\
Brosur/Leaflet & & \\
$\quad$ Ya & 20 & 50,0 \\
$\quad$ Tidak & 20 & 50,0 \\
Penyuluhan & & \\
$\quad$ Ya & 16 & 40,0 \\
$\quad$ Tidak & 24 & 60,0 \\
Informasi dari orang lain (teman) & & \\
$\quad$ Ya & 29 & 73,0 \\
$\quad$ Tidak & 11 & 28,0 \\
TV/Radio/Koran & & \\
Ya & 21 & 53,0 \\
Tidak & 19 & 48,0 \\
\hline
\end{tabular}

Tabel 4. Tingkat pengetahuan tentang infeksi gonore melalui hubungan seksual berisiko tinggi

\begin{tabular}{lcc}
\hline \multicolumn{1}{c}{ Transmisi } & Frekuensi & Persentase (\%) \\
\hline $\begin{array}{l}\text { Hubungan Seksual } \\
\text { Per vagina }\end{array} \quad$ & \\
$\quad$ Sangat sering & 1 & 2,5 \\
Sering & 8 & 17,5 \\
Cukup sering & 9 & 20,0 \\
Tidak pernah & 15 & 22,5 \\
Pernah & & 37,5 \\
Per anal & 3 & \\
Sangat sering & 4 & 7,5 \\
Sering & 7 & 10,0 \\
Cukup sering & 8 & 17,5 \\
Tidak pernah & 18 & 20,0 \\
Pernah & & 45,0 \\
Per oral & & \\
Sangat sering & 4 & 10,0 \\
Sering & 4 & 10,0 \\
Cukup sering & 7 & 17,5 \\
Tidak pernah & 9 & 22,5 \\
Pernah & 16 & 40,0 \\
\hline
\end{tabular}


Lanjutan Tabel 4. Tingkat pengetahuan tentang infeksi gonore melalui hubungan seksual berisiko

\begin{tabular}{lcc}
\hline \multicolumn{1}{c}{ Transmisi } & Frekuensi & Persentase (\%) \\
\hline $\begin{array}{l}\text { Pencegahan dengan } \\
\text { menggunaan Kondom }\end{array}$ & & \\
$\quad$ Sangat sering & 1 & 2,5 \\
$\quad$ Sering & 2 & 5,0 \\
$\quad$ Cukup sering & 4 & 10,0 \\
Tidak pernah & 12 & 30,0 \\
$\quad$ Pernah & 21 & 52,5 \\
Pasangan Seksual & & \\
Lebih dari satu pasangan & & \\
$\quad$ Benar & 40 & 100,0 \\
Salah & 0 & 0,0 \\
PSK & & \\
Benar & 37 & 93,0 \\
Salah & 3 & 8,0 \\
Homokseksual & & \\
Benar & 35 & 88,0 \\
Salah & 5 & 13,0 \\
Tidak memakai kondom & & \\
Benar & 37 & 93,0 \\
Salah & 3 & 8,0 \\
\hline
\end{tabular}

Berdasarkan hasil analisis deskriptif pada Tabel 4, diinformasikan bahwa dari 40 pasien yang pernah menderita gonore di RSUD Dr. Saiful Anwar Malang, paling banyak sebesar $37,5 \%$ responden menyatakan pernah melakukan hubungan seks per vaginal (melalui vagina) yang dilakukan dalam seminggu terakhir. Selanjutnya, sebesar $45,0 \%$ responden menyatakan pernah melakukan hubungan seks per anal (melalui anal/anus/ dubur) yang dilakukan dalam seminggu terakhir, dan sebesar $40,0 \%$ responden menyatakan pernah melakukan hubungan seks per oral (melalui mulut) yang dilakukan dalam seminggu terakhir. Berikutnya sebesar $52,5 \%$ responden menyatakan bahwa mereka atau pasangan seks mereka selalu menggunakan kondom setiap kali berhubungan seks. Lalu, sebanyak $100 \%$ responden menyatakan benar bahwa infeksi gonore dapat ditularkan dengan berhubungan lebih dari satu pasangan. Hal ini menunjukkan bahwa semua pasien yang pernah menderita gonore di RSUD Dr. Saiful Anwar Malang yang terlibat dalam penelitian ini menyatakan benar bahwa infeksi gonore dapat ditularkan dengan berhubungan lebih dari satu pasangan. Sebanyak 93\% responden menyatakan benar bahwa infeksi gonore dapat ditularkan dengan berhubungan dengan PSK, dan sebanyak 88\% responden menyatakan benar bahwa berhubungan sejenis (homoseksual) dapat menularkan infeksi gonore serta sebanyak $93 \%$ responden menyatakan benar bahwa tidak menggunakan kondom dapat menularkan infeksi gonore, dan sebesar $8 \%$ responden menyatakan salah bahwa tidak menggunakan kondom dapat menularkan infeksi gonore.

Hal ini menunjukkan bahwa sebagian besar sampel yang terlibat dalam penelitian ini menyatakan bahwa mereka mengetahui faktor hubungan seksual berisiko tinggi yang dapat menyebabkan terjadinya infeksi gonore. 
Hasil analisis dengan menggunakan analisis jalur (path analysis) untuk mengetahui ada tidaknya pengaruh variabel eksogen terhadap variabel endogen secara langsung maupun tidak langsung melalui variabel mediasi. Kriteria pengujian hipotesis secara langsung menyatakan bahwa apabila nilai probabilitas < level of significant (alpha $=a$ ), maka dinyatakan ada pengaruh signifikan variabel eksogen terhadap variabel endogen. Pengujian hipotesis dapat diketahui melalui Tabel 5. Berdasarkan Tabel 5, pengaruh tingkat pengetahuan terhadap hubungan seksual berisiko tinggi menghasilkan nilai $T$ statistics sebesar 2,988 dengan probabilitas (P) sebesar 0,005. Hasil pengujian tersebut menunjukkan bahwa probabilitas < alpha $(5 \%)$. Hal ini berarti terdapat pengaruh signifikan tingkat pengetahuan terhadap hubungan seksual berisiko tinggi. Koefisien jalur pengaruh tingkat pengetahuan terhadap hubungan seksual berisiko tinggi adalah sebesar 0,441 menunjukkan tingkat pengetahuan berpengaruh positif terhadap hubungan seksual berisiko tinggi. Hal ini berarti semakin tinggi tingkat pengetahuan maka dapat meningkatkan hubungan seksual berisiko tinggi.
Pengujian hipotesis tidak langsung dimaksudkan untuk mengetahui pengaruh variabel eksogen terhadap variabel endogen melalui variabel mediasi. Kriteria pengujian menyatakan bahwa apabila jalur 1 (pengaruh eksogen terhadap mediasi) berpengaruh signifikan dan jalur 2 (pengaruh mediasi terhadap endogen) berpengaruh signifikan, maka dinyatakan terdapat pengaruh signifikan variabel eksogen terhadap variabel endogen melalui variabel mediasi.

Hasil pengujian hipotesis tidak langsung tingkat pengetahuan terhadap infeksi gonore melalui hubungan seksual berisiko tinggi dapat diketahui melalui Gambar 1. Gambar 1 menginformasikan pengaruh tingkat pengetahuan terhadap hubungan seksual berisiko tinggi menghasilkan pengujian yang dinyatakan berpengaruh signifikan dan pengaruh hubungan seksual berisiko tinggi terhadap infeksi gonore menghasilkan pengujian yang dinyatakan tidak berpengaruh signifikan. Hal ini berarti tidak terdapat pengaruh signifikan tingkat pengetahuan terhadap infeksi gonore melalui hubungan seksual berisiko tinggi.

Tabel 5. Pengujian hipotesis secara langsung

\begin{tabular}{llccc}
\hline \multicolumn{1}{c}{ Eksogen } & \multicolumn{1}{c}{ Endogen } & Coeff. & T Stat. & Prob. \\
\hline Tingkat pengetahuan & Hubungan seksual berisiko tinggi & 0,441 & 2,988 & 0,005 \\
Tingkat pengetahuan & Infeksi gonore & 0,249 & 1,472 & 0,150 \\
Hubungan seksual berisiko tinggi & Infeksi gonore & 0,235 & 1,391 & 0,173 \\
\hline
\end{tabular}

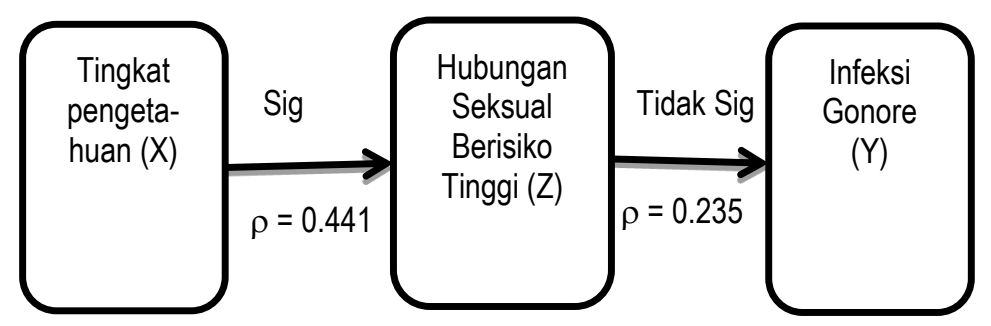

Gambar 1. Diagram pengujian hipotesis pengaruh tidak langsung 
Tabel 6. Pengaruh dominan terhadap infeksi gonore

\begin{tabular}{|c|c|c|c|c|c|}
\hline Eksogen & Mediasi & Endogen & $\begin{array}{l}\text { Direct } \\
\text { Coef. }\end{array}$ & $\begin{array}{l}\text { Indirect } \\
\text { Coef. }\end{array}$ & $\begin{array}{l}\text { Total } \\
\text { Coef. }\end{array}$ \\
\hline $\begin{array}{l}\text { Tingkat } \\
\text { pengetahuan }\end{array}$ & & $\begin{array}{l}\text { Hubungan seksual } \\
\text { Berisiko tinggi }\end{array}$ & 0,441 & & 0,441 \\
\hline $\begin{array}{l}\text { Hubungan seksual } \\
\text { Berisiko tinggi }\end{array}$ & & $\begin{array}{l}\text { Infeksi } \\
\text { gonore }\end{array}$ & 0,235 & & 0,235 \\
\hline $\begin{array}{l}\text { Tingkat } \\
\text { pengetahuan }\end{array}$ & $\begin{array}{l}\text { Hubungan seksual } \\
\text { Berisiko tinggi }\end{array}$ & $\begin{array}{l}\text { Infeksi } \\
\text { gonore }\end{array}$ & 0,249 & 0,104 & 0,353 \\
\hline
\end{tabular}

Variabel eksogen yang paling berpengaruh terhadap variabel endogen dapat diketahui melalui total efek yang paling tinggi. Hasil perhitungan total efek dirangkum dalam Tabel 6 yang menunjukkan bahwa variabel yang paling berpengaruh dominan terhadap infeksi gonore adalah variabel tingkat pengetahuan dengan total efek sebesar 0,353 . Sehingga dapat disimpulkan bahwa tingkat pengetahuan merupakan variabel yang paling berpengaruh atau memiliki pengaruh yang paling dominan terhadap infeksi gonore.

\section{Pembahasan}

Pada penelitian ini didapatkan 40 $(100 \%)$ responden adalah pasien yang pernah terinfeksi gonore di RSUD Dr. Saiful Anwar Malang berjenis kelamin laki-laki dikarenakan peneliti hanya mengambil sampel dari pasien gonore yang berjenis kelamin laki-laki saja. Tahun 2017-2019 pasien gonore di RSUD Dr. Saiful Anwar Malang terbanyak pada pasien berjenis ke-lamin lakilaki. Hal ini dipengaruhi oleh berbagai faktor, salah satunya adalah perilaku seksual/pola berhubungan seksual yang berisiko yaitu hubungan seks anogenital tanpa kondom, orogenital dan serosorting. Menurut Niode \& Jayadi (2016) dalam penelitiannya dengan judul "Pencegahan dan Tatalaksana Infeksi Menular Seksual serta Infeksi Human Immunodeficiency Virus (HIV) pada Laki-Laki yang Berhubungan Seksual dengan LakiLaki" telah dijelaskan hubungan seks anogenital tanpa kondom, menjadi salah satu cara transmisi terjadinya IMS dan HIV yang paling efisien karena lapisan rektum sangat rentan, tipis, dan mudah robek, sehingga jika terdapat mikrolesi saja sudah memungkinkan menjadi jalan masuk infeksi. ${ }^{6}$

Biasanya pasangan seksual reseptif lebih berisiko dibandingkan pasangan seksual insertif serta hubungan seksual orogenital juga berisiko menularkan IMS dan HIV meski risikonya lebih rendah apalagi didukung dengan adanya luka atau lesi di dalam rongga mulut maka penyebaran infeksipun akan mudah dan cepat terjadi. Selain itu, juga terdapat perilaku seksual berisiko LSL yaitu serosorting. Serosorting adalah perilaku seseorang untuk memilih pasangan seksual dengan status serologi HIV yang sama dan melakukan hubungan seksual tanpa kondom dengan pasangannya tersebut. 6

\section{Kelompok Risiko Tinggi}

Penelitian ini mendapatkan bahwa kelompok RISTI terbanyak terdapat pada kelompok LSL sebesar $52.5 \%$ (Tabel 2). LSL merupakan salah satu kelompok risiko tinggi (risti) untuk tertular IMS dan HIV. Hal ini berkaitan dengan aktivitas seks yang mereka lakukan umumnya adalah seks anal dan oral. Berhubungan seksual per anal mempunyai risiko perlukaan pada daerah tersebut dikarena daerah anal/anus bersifat tidak elastis, sehingga ketika ada luka di daerah anus dan pasangan seksual terkena IMS dan HIV maka akan lebih mudah ditularkan. ${ }^{7}$ 
LSL dikhawatirkan akan menjadi salah satu sumber utama penularan HIV yang bersifat potensial, mengingat bahwa mereka adalah laki-laki heteroseksual yang memiliki orientasi seks kepada lawan jenis dan sesama jenis (biseksual). ${ }^{8}$ Bila kondisi seperti ini tidak segera ditangani dengan baik, dikhawatirkan penularan HIV tidak hanya terkonsentrasi pada populasi kunci saja melainkan akan dengan cepat menyebar secara luas ke masyarakat umum.

Pengaruh Pengetahuan terhadap Kejadian Infeksi Gonore

Dari hasil penelitian, seseorang yang memiliki pengetahuan yang baik, seperti mengetahui faktor risiko, sumber penularan infeksi gonore, cara pencegahan, dan cara penyembuhannya, maka bisa menekan peningkatan kejadian infeksi gonore. Hal ini dapat diketahui bahwa sebesar $85 \%$ pernah mendengar tentang infeksi gonore melalui media sosial. Saat ini informasi dapat dengan mudah kita ketahui yang ditunjang dengan adanya perkembangan teknologi yang cukup pesat termasuk kemajuan gadget sehingga informasi dapat kita ketahui melalui media sosial.

Menurut Notoatmodjo (2003) mata merupakan indera yang paling banyak menyalurkan pengetahuan ke dalam otak. Kurang lebih $75 \%$ sampai $87 \%$ dari pengetahuan manusia diperoleh/disalurkan melalui mata, sedangkan $13 \%$ sampai $25 \%$ lainnya tersalur melalui indera yang lain. Berdasarkan hal tersebut media sosial merupakan sarana yang dapat membantu untuk mempermudah penyampaian dan penerimaan informasi, sehingga dapat membantu meningkatkan pengetahuan. Media cetak maupun elektronik mampu meningkatkan pengetahuan yang lebih tinggi daripada sebelumnya. ${ }^{4}$

Pada Tabel 1 dapat diketahui bahwa $75 \%$ responden memiliki pendidikan terakhir SMA yang berarti rata-rata responden sudah memiliki pengetahuan yang baik. Hasil ini sejalan dengan penelitian Fatimah, 2013 di Wilayah Kerja Puskesmas Kom Yos Sudarso Pontianak yang menunjukkan tingkat pengetahuan yang baik yaitu sebesar $54 \% .{ }^{9}$ Jadi, dapat dikatakan bahwa sebagian besar orang dengan pengetahuan mengenai infeksi gonore yang baik cenderung memiliki perilaku pencegahan terhadap penularan yang baik pula.

Hal serupa ditemukan pada penelitian ini di saat wawancara nonstructural yang menunjukkan bahwa pengetahuan dari responden tidak berpengaruh signifikan terhadap hubungan seksual berisiko tinggi dan kejadian infeksi gonore.

Berdasarkan fenomena di atas, ada satu hal yang memoderasi pengaruh antara pengetahuan dengan hubungan seksual berisiko tinggi terhadap kejadian infeksi gonore, yaitu kemajuan teknologi dalam hal ini media sosial yang memudahkan seseorang untuk mengakses artikel/berita/ jurnal terkait kondisi kesehatannya. Selain itu, media sosial memudahkan mereka untuk menjangkau kelompokkelompok gay atau lesbian, gay, biseksual, dan transgender (LGBT).

\section{Hubungan Seksual Berisiko Tinggi terhadap Kejadian Infeksi Gonore}

Pada penelitian ini, sebesar $45,0 \%$ responden menyatakan pernah melakukan hubungan seksual per anal (melalui anal/ anus/dubur) yang dilakukan dalam seminggu terakhir. Kemudian sebesar 40,0\% responden menyatakan pernah melakukan hubungan seksual per oral (melalui mulut) yang dilakukan dalam seminggu terakhir. Berikutnya, sebesar $52,5 \%$ responden menyatakan bahwa mereka atau pasangan seksual mereka selalu menggunakan kondom setiap kali berhubungan seksual (Tabel 3). Hal ini menunjukkan adanya perilaku hubungan seksual yang berisiko tinggi yang menjadi transmisi penyakit infeksi menular seksual yaitu infeksi gonore. 
Kejadian ini diperkuat dengan pernyataan salah satu responden berinisial $\mathrm{X}$ ketika peneliti memberikan pertanyaan nonstructural terkait keamanan selama berhubungan seksual yaitu dengan penggunaan kondom atau tidak selama berhubungan seksual. Responden $\mathrm{X}$ memberikan jawaban jika ia sebelumnya jarang menggunakan kondom namun semenjak terinfeksi gonore, ia berupaya untuk rutin menggunakan kondom. Namun pada kondisi tertentu, responden kembali tidak rutin menggunakan kondom karena faktor ketidaknyamanan dan merasa tidak puas selama berhubungan seksual. Dari jawaban res-ponden dapat dikatakan jika pemakaian kondom sebagai pencegahan penularan IMS adalah tidak.

Maka, didapatkan kaitan antara pengetahuan responden dengan pentingnya penggunaan kondom. Responden tersebut memiliki pengetahuan sangat baik, namun adanya faktor ketidaknyamanan menyebabkan responden abai terhadap keamanan dalam berhubungan terlebih dengan pasangan seksual yang baru saja dikenal, sehingga mudah untuk memutuskan tidak menggunakan kondom.

\section{Pengujian Hipotesis secara Langsung}

Hasil pengujian hipotesis secara langsung pada Tabel 5 menunjukkan bahwa pengaruh tingkat pengetahuan terhadap infeksi gonore menghasilkan nilai $T$ statistics sebesar 1,472 dengan probabilitas sebesar 0,150 . Hasil pengujian tersebut menunjukkan bahwa probabilitas > alpha $(5 \%)$. Hal ini berarti terdapat pengaruh yang tidak signifikan antara tingkat pengetahuan terhadap infeksi gonore. Hal ini karena bisa dipengaruhi oleh beberapa faktor seperti jumlah responden yang diteliti kurang sehingga tidak bisa mewakili populasi, dan atau faktor jawaban/ pernyataan responden yang tidak sesuai sehingga dapat mempengaruhi hasil penelitian.

Sejalan dengan penelitian Afriana, 2012 menunjukkan bahwa pendidikan tidak berhubungan dengan kejadian infeksi gonore pada WPS. (OR $0.9895 \% \mathrm{Cl} 0.78-1.23$ ). secara statistik tidak bermakna sehingga bisa dikatakan bahwa risiko untuk terinfeksi gonore pada WPS yang pendidikan tinggi maupun rendah adalah sama. ${ }^{10}$

Hasil penelitian mengenai pengaruh hubungan seksual berisiko tinggi terhadap infeksi gonore menghasilkan nilai $T$ statistics sebesar 1,391 dengan probabilitas sebesar 0,173 . Hasil pengujian tersebut menunjukkan bahwa probabilitas > alpha (5\%). Hal ini berarti terdapat pengaruh yang tidak signifikan hubungan seksual berisiko tinggi terhadap infeksi gonore. Kemungkinan ini dapat disebabkan oleh pengumpulan data dilakukan hanya berasal dari kuesioner, sehingga ada peluang responden kurang jujur saat mengisi kuesioner dan didapatkan hasil negatif palsu. Faktor lain adalah responden melakukan hubungan seksual berisiko tinggi atas dasar untuk memenuhi hasrat seksual, suka sama suka, dan rasa ingin mencoba tanpa memikirkan dampak yang telah dilakukan.

Hasil penelitian ini sejalan dengan penelitian Cempaka P \& Kardiwinata, 2012 berjudul "Pola Hubungan Seksual dan Riwayat IMS pada Gay di Bali' menunjukkan hubungan seksual pada gay dilakukan secara oral mau-pun anal seks dengan frekuensi penggunaan kondom pada gay sebesar $57,8 \%$, dari $57 \%$ (26 gay) tersebut tidak semuanya konsisten menggunakan kondom, yang konsisten hanya 65,4\% (17 gay) sehingga memiliki perilaku hubungan seksual yang sangat berisiko terkena IMS. ${ }^{11}$

\section{Pengujian Hipotesis secara Tidak Langsung}

Gambar 1 menginformasikan pengaruh tingkat pengetahuan terhadap hubungan seksual berisiko tinggi menghasilkan pengujian yang dinyatakan berpengaruh signifikan dan pengaruh hubungan seksual berisiko tinggi terhadap infeksi gonore menghasilkan pengujian yang dinyatakan tidak berpengaruh signifikan. 
Hal ini berarti tidak terdapat pengaruh signifikan tingkat pengetahuan terhadap infeksi gonore melalui hubungan seksual berisiko tinggi.

Hasil penelitian ini sejalan dengan penelitian Fatimah (2013) bahwa sebagian besar responden yang menjadi objek penelitiannya memiliki tingkat pengetahuan yang cukup mengenai IMS. ${ }^{10}$ Hasil penelitian ini, sama hal nya dengan penelitian yang telah dilakukan oleh Panenga (2014) sebelumnya dimana responden penelitiannya berada pada kategori cukup dengan persentasi $56,05 \% .{ }^{12}$

Adanya perbedaan hasil penelitian sebelumnya dengan hasil penelitian ini bisa disebabkan oleh penggunaan parameter yang berbeda dan sampel yang digunakan. Oleh karena itu, peneliti berpendapat bahwa pengetahuan sangat penting dalam membentuk sikap dan perilaku dalam berhubungan seksual. Dalam hal ini, infeksi gonore tidak dipengaruhi oleh tingkat pengetahuan ataupun hubungan seksual berisiko tinggi. Namun, tingkat pengetahuan akan mempengaruhi hubungan seksual berisiko tinggi.

\section{Kesimpulan}

Dari penelitian ini dapat disimpulkan bahwa tingkat pengetahuan terhadap hubungan seksual berisiko tinggi memiliki pengaruh yang signifikan terhadap infeksi gonore, namun tidak berpengaruh signifikan terhadap kejadian infeksi gonore. Selain itu, tingkat pengetahuan tidak berpengaruh signifikan terhadap infeksi gonore melalui hubungan seksual berisiko tinggi. Serta, hubungan seksual berisiko tinggi tidak berpengaruh signifikan terhadap kejadian infeksi gonore.

\section{Saran}

Saran yang dapat diberikan adalah: (1). Memberikan pemahaman pada populasi kunci terutama LSL tentang perlunya memakai kondom secara konsisten, (2). Penderita untuk mendapatkan atau mencari informasi kesehatan kepada pihak yang ahli di bidangnya atau melalui media informasi, (3). Evaluasi dan monitoring bulanan terhadap program pembagian kondom secara langsung pada pengguna, (4). Meningkatkan intensitas penyuluhan pada kelompok risti mengenai penularan, pencegahan dan gejala mengenai infeksi menular seksual, dan melakukan perbaikan pada penyuluhan selanjutnya atau mungkin dengan pendekatan yang berbeda terhadap penderita IMS, (5). Bagi peneliti selanjutnya dapat melakukan penelitian lanjutan pembuktian tentang penurunan penularan infeksi gonore, (6). Tindakan pencegahan perlu pendekatan yang komprehensif melalui penurunan insidensi gonore (penggunaan kondom, skrining populasi berisiko, terapi efektif, dan penatalaksanaan pasangan seksual yang efektif).

\section{Daftar Pustaka}

1. Centers for Disease Control and Prevention. Sexually Transmitted Disease Surveillance 2016. Atlanta: U.S. Department of Health and Human Services. 2017.

2. Departemen Kesehatan RI. Infeksi Menular Seksual dan HIVIAIDS. Analisis Kecenderungan Perilaku Berisiko Terhadap HIV di Indonesia. Hasil Surveilans Terpadu Biologis dan Perilaku (STBP) tahun 2013. Dirjen Pengendalian Penyakit dan Penyehatan Lingkungan. Jakarta: Departemen Kesehatan RI. 2014.

3. Widasmara D. Epidemiologi Infeksi Menular Seksual. Infeksi Menular Seksual. Edisi ke-4. Jakarta: Balai Penerbitan Fakultas Kedokteran Universitas Indonesia. 2017. HIm. 3-9.

4. Notoatmodjo S. Promosi Kesehatan dan dan Teori-Teori Kesehatan. Jakarta: Rineka Cipta. 2003. 
5. Centers for Disease Control and Prevention. People Who have STDs are More Likely to Get HIV, When Compared to People Who Do. (Online). 2017. https:// www.cdc.gov/std/hiv/stdfact-std-hivdetailed.htm.

6. Niode NJ \& Jayadi NN. Pencegahan dan Tatalaksana Infeksi Menular Seksual serta Infeksi Human Immunodeficiency Virus (HIV) pada Laki-Laki yang Berhubungan Seksual dengan Laki-Laki. MDVI. 2016; 43(3):119-23.

7. Suwandani R. Pengetahuan dan Sikap Berisiko Waria dengan Kejadian Infeksi Menular Seksual (IMS) pada Waria di Sidoarjo. JBE. 2015; 3(1):38.

8. Firdaus $S$ \& Agustin $H$. Faktor Risiko Kejadian HIV pada Komunitas LSL (Lelaki Seks dengan Lelaki) Mitra Yayasan Lantera Minangkabau Sumatera Barat. J Kesehat Komunitas. 2013; 2:94-9. doi:10.25311/jkk.vol2.iss2.52.

9. Fatimah S. Hubungan antara Pengetahu- an dan Sikap Pasien Infeksi Menular Seksual (IMS) dengan Perilaku Pencegahan Penularan IMS di Wilayah Kerja Puskesmas Kom Yos Sudarso Pontianak. Disertasi. Tidak diterbitkan. Pontianak: Universitas Tanjungpura. 2013.

10. Afriana N. Faktor-Faktor yang Berhubungan dengan Kejadian Infeksi Gonore pada Wanita Penjaja Seks Komersial di 16 Kabupaten/Kota Indonesia (Analisis Data Sekunder Survei Terpadu Biologi dan Perilaku 2011). Tesis. Tidak diterbitkan. Depok. 2012.

11. Cempaka PPR \& Kardiwinata MP. Pola Hubungan Seksual dan Riwayat IMS pada Gay di Bali. Arc Com Health. 2012; 1(2):84-89.

12. Panenga TD, Noor MR, \& Triawanti. Tingkat Pengetahuan tentang Penyakit Menular Seksual pada Siswa SMA Negeri di Banjarmasin. Jurnal Berkala Kedokteran. 2014; 1(2):95-101. 